\title{
Ascites of Spleenic Origin in a Mongrel Female Dog - A Case Report
}

\author{
V. S. Dabas, D. N. Suthar, C. F. Chaudhari, L. C. Modi and P. D. Vihol \\ Department of Surgery and Radiology, \\ Veterinary College, Navsari Agricultural University, Navsari, Gujarat, India. \\ E-mail : vsdabas@yahoo.co.in
}

Received: 15-12-2010, Accepted: 12-01-2011, Published Online: 04-06-2011

Ascites refers to the accumulation of serous fluid in the peritoneal cavity; caused by a variety of etiological factors viz. chronic hepatic failure, congestive heart failure, nephritic syndrome, malnutrition, hypoproteinemia, protein losing enteropathy, heavy parasitism and abdominal neoplasia of different origin (Pradhan, et al., 2008 and Turkar et al., 2009). Since, ascites is always a sign of disease, the investigation should be aimed at identifying the primary underlying problem.

\section{Case history and clinical observations}

Eight years old mongrel female dog was presented with the history of progressive abdominal distention, inactiveness and weakness since four weeks. The animal was repeatedly treated by local veterinarians without success. Clinically, there was pyrexia $\left(104.5^{\circ} \mathrm{F}\right)$ and markedly distended abdomen with a palpable fluid thrill. The animal was dehydrated and the mucous membranes were pale. Haematological studies revealed $11.5 \mathrm{gm} \%$ of $\mathrm{Hb}$ along with leucocytosis associated with neutrophilia. Serum creatinine and SGOT levels were $1.135 \mathrm{mg} / \mathrm{dl}$ and $6.364 \mathrm{IU} / \mathrm{L}$, respectively. The faeces was negative for any parasitic ova. Accordingly, the case was diagnosed as ascites of infective origin and decided for medicinal management.

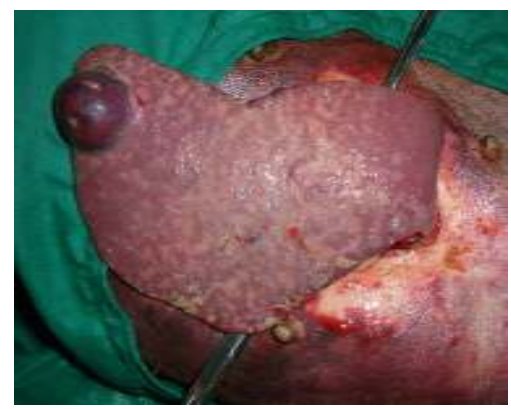

Figure-1. Splenomegaly with growth on poeterior border

\section{Treatment and Discussion}

The animal was parentally treated with Inj. ceftriaxone@500mg, BID; Inj. frusemide @ 2.0 $\mathrm{mg} / \mathrm{kg}, \mathrm{BID}$; Inj. pheniramine meleate @ $1.0 \mathrm{ml}$ and Inj. ketoprofen @ $2 \mathrm{ml}$ daily for a week. The owner was advised to feed the animal with two eggs daily for 15 days. Subsequently, reduction in abdominal distension was observed from $5^{\text {th }}$ day and the animal became completely healthy by $15^{\text {th }}$ day.

Later, the case was again brought to the hospital after a month's break with slightly distended abdomen. Palpation revealed a hard mass posterior to the left costal arch. Hence, the routine mid line exploratory laparotomy was performed under general anaesthesia using xylazine HCL $(1.0 \mathrm{mg} / \mathrm{kg})$ and ketamine HCL $(10 \mathrm{mg} / \mathrm{kg})$, intravenously. To the utmost surprise, the spleen was found five times enlarged with $2.5 \mathrm{~cm}$ diameter nodule on the posterior border of its diaphragmatic surface (Fig.1). Subsequently, it was surgically removed and the flaps were sutured with \# 3/0 chromic catgut (Fig.2). The laparotomy wound was closed in routine manner.

Post-operative parental antibiotic (Inj. procaine penicillin), anti-histaminic and anti-inflammatory drugs in prescribed doses along with oral haematinic

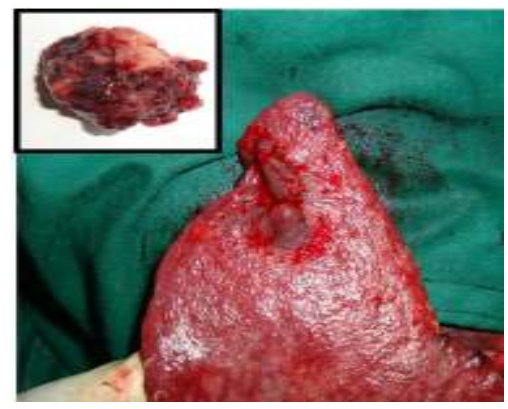

Figure-2. Spleen after removal of growth 
preparation were continued for a week. Surgical wound was dressed daily and the skin sutures were removed on $12^{\text {th }}$ post-operative day. However, the animal died on $15^{\text {th }}$ day post-operative. Histopathologically, the growth was found to be a follicular necrosis and lymphocytosis.

Haemoconcentration and leucocytosis with increase in neutrophills observed in the present case were also reported by Cornelius et al. (1975) and Kumar, (2002). Similarly, the clinical symptoms exhibited by the animal in the present study correlated the findings of Ranjan et al. (1991) and Bhojne and Dakshinkar, (2000) in the patients suffered with ascites.

Since, the animal was suffering with chronic illness and the clinico-pathological parameters were also suggestive of infection, the line of treatment was restricted to the use of higher antibiotic along with supportive therapy which, responded uneventfully for the first time. However, the condition relapsed after a month's period and could not be cured even following the removal of the spleenic pathology. This supported the findings of Eikmeier, (1960) and Jaksch, (1966); wherein frequent peritonitis, abdominal tumors and spleenic disorder are reported to be the causative factors for ascites. Further, the irreversible pathomorphological changes due to the prolonged illness and spleenic neoplasm (Jaksch, 1994) might be responsible for the speenomegaly and eventual death of the animal.

\section{References}

1. Bhojne, G.R. and Dakshinkar, N.P. (2000). Vet. Med. J. 24:265

2. Cornelius, L.M., Thrall, D.E., Halliwell, W.H., Frank, G.M., Kern, A.J. and Wood C.B. (1975). J. Am. Vet. Med. Assoc. 167:220-228.

3. Eikmeier, H. (1960). Diagnostische untersuchungen uber die leberkrankungen des hundes. Zbl. Vet. Med. 7: 22-58.

4. Jaksch, W. (1966). Kardiologische probleme in de kleintierpraxis. Kleintier Praxis. 11:19.

5. Jaksch, W. (1994). Diagnose und therapie von leberkrankheiten bei kleintieren. Wien. Tierarztl. Monatsschr. 61: 127-138.

6. Kumar, S. (2002).Thesis Abstract. J. Canine Dev. Res. 2:78.

7. Pradhan, M.S., Dakshinkar N.P., Waghaye, U.G. and Bodkhe, A.M. (2008). Successful treatment of ascites of hepatic origin in Dog. Veterinary World. 1(1):23.

8. Rajan, T.S.S., Suresh, R.V., Rasheed, M.A. and Pattabiraman, S.R. (1991). Ind. Vet. J. 68:1067 1068.

9. Turkar, Sujata., Randhawa, C.S. and Uppal, S.K. (2009). Ascites associated with ancylostomiasis in a pup: A case report. Intas Polivet. 10(2): 357:359. 